\title{
Assessment of Exercise Intolerance in Patients with Pre-Dialysis CKD with Cardiopulmonary Function Testing: Translation to Everyday Practice
}

\author{
Eva Pella $^{\mathrm{a}}$ Afroditi Boutou $^{\mathrm{b}}$ Marieta P. Theodorakopoulou ${ }^{\mathrm{a}}$ Pantelis Sarafidis $^{\mathrm{a}}$ \\ aDepartment of Nephrology, Hippokration Hospital, Aristotle University of Thessaloniki, Thessaloniki, Greece; \\ bepartment of Respiratory Medicine, G. Papanikolaou Hospital, Thessaloniki, Greece
}

\begin{abstract}
Keywords
Cardiopulmonary exercise testing - Chronic kidney disease - Exercise intolerance . Cardiovascular reserve . $\mathrm{VO}_{2}$ peak $\cdot \mathrm{VO}_{2} \max$
\end{abstract}

\begin{abstract}
Background: Chronic kidney disease (CKD) is often characterized by increased prevalence of cardiovascular risk factors and increased incidence of cardiovascular events and death. Reduced cardiovascular reserve and exercise intolerance are common in patients with CKD and are associated with adverse outcomes. Summary: The gold standard for identifying exercise limitation is cardiopulmonary exercise testing (CPET). CPET provides an integrative evaluation of cardiovascular, pulmonary, hematopoietic, neuropsychological, and metabolic function during maximal or submaximal exercise. It is useful in clinical setting for differentiation of the causes of exercise intolerance, risk stratification, and assessment of response to relevant treatments. A number of recent studies have used CPET in patients with pre-dialysis CKD, aiming to assess the cardiovascular reserve of these individuals, as well as the effect of interventions such as exercise training programs on their functional capacity. This review provides an
\end{abstract}

(C) 2021 S. Karger AG, Basel

www.karger.com/ajn in-depth description of CPET methodology and an overview of studies that utilized CPET technology to assess cardiovascular reserve in patients with pre-dialysis CKD. Key Messages: CPET can delineate multisystem changes and offer comprehensive phenotyping of factors determining overall cardiovascular risk. Potential clinical applications of CPET in CKD patients range from objective diagnosis of exercise intolerance to preoperative and long-term risk stratification and providing intermediate endpoints for clinical trials. Future studies should delineate the association of CPET indexes, with cardiovascular and respiratory alterations and hard outcomes in CKD patients, to enhance its diagnostic and prognostic utility in this population. @ $2021 \mathrm{~S}$. Karger AG, Basel

\section{Introduction}

Chronic kidney disease (CKD) is a worldwide public health problem, with increasing incidence and prevalence, high costs, and poor outcomes [1]. It is currently estimated that more than 850 million individuals worldwide have kidney diseases [2], while the prevalence of CKD is estimated at about $9 \%$ of the world population,

\footnotetext{
Karger"
}

Correspondence to:

Pantelis Sarafidis, psarafidis11@yahoo.gr 
increasing to $12 \%$ in several Western countries [3]. As a result, CKD currently lists among the fastest growing global causes of death and is projected to become the fifth global cause of death by 2040 [4]. Several epidemiological studies have shown that patients with CKD are at increased risk for cardiovascular events and all-cause mortality, while elevated levels of urine albumin excretion (i.e., moderately or severely increased albuminuria) are also associated with an increased risk of cardiovascular events, as well as a faster progression of CKD $[5,6]$. Classical cardiovascular risk factors (including age, hypertension, diabetes mellitus, dyslipidemia, obesity, and smoking), as well as nonclassical risk factors relevant to CKD and the uremic environment per se (i.e., anemia, disturbed metabolism of calcium and phosphate, and others) are highly prevalent in patients with CKD and also contribute to the risk of developing cardiovascular disease [7-9]. Therefore, cardiovascular complications are the principal cause of death in patients with CKD [10].

Cardiorespiratory fitness reflects the ability of the cardiovascular and respiratory systems to transport oxygen to the working muscles of the human body during physical activity. Impaired cardiorespiratory fitness is strongly associated with early all-cause and cardiovascular-related mortality $[11,12]$. Patients with CKD have lower cardiorespiratory fitness than the general population; this occurs early in the disease process, declines further with renal function drop, and is also associated with increased aortic stiffness, poor left ventricular function, and higher risk of cardiovascular events [12-14]. Thus, exercise intolerance, a prognostic factor of morbidity and mortality, is inherently associated with CKD [15-17]. The ability of these patients to exercise can be related to a number of factors, including cardiac function disturbances, endothelial dysfunction, arterial stiffness, morphological and functional abnormalities of skeletal muscles, dysautonomia of nervous system, anemia, depression, and others. The above-mentioned causes lead these patients to inactivity, diminished functional capacity, feeling of fatigue, social isolation, and finally, low quality of life $[18,19]$.

Cardiopulmonary exercise testing (CPET) is a dynamic, noninvasive technique that is useful in various clinical settings for diagnosis, risk stratification, and the evaluation of response to cardiopulmonary therapies [20]. It is long considered to be the gold standard for evaluating the degree and differentiating the causes, by unmasking physiological mechanisms of exercise intolerance [21, 22]. A number of observational studies and randomized trials have applied CPET technology to evaluate cardiopulmonary reserve in patients with pre-dialysis CKD and end-stage kidney disease. In this review, we attempt to provide an in-depth description of CPET methodology and the underlying exercise physiology, its key findings depending on the underlying cause and pathophysiology of exercise limitation, as well as an overview of studies that utilized CPET technology to assess cardiovascular reserve in patients with pre-dialysis CKD, that is, a population of patients that is highly prevalent, but rather poorly characterized in terms of exercise physiology.

\section{Cardiopulmonary Exercise Testing}

CPET provides an integrative assessment of the cardiovascular, pulmonary, muscular, and neuropsychological responses during exercise; this allows the assessment of the physiological reserves of these systems that are not adequately reflected through the measurement of individual organ system at rest $[22,23]$. CPET should be considered the gold standard for evaluating the causes of exercise intolerance, especially in patients with cardiovascular or respiratory disorders, and is based on the principle that system failure typically occurs while the system (e.g., muscle-energetic, cardiovascular, or pulmonary) is under stress [21]. This noninvasive, dynamic test permits the evaluation of both submaximal and peak exercise responses, providing the physician with relevant information for clinical decision-making [24]. CPET is being used increasingly in a wide spectrum of clinical applications for evaluation of undiagnosed exercise intolerance and for objective determination of functional capacity and impairment $[23,24]$.

During CPET, a vast number of "routine" exercise testing variables and more sophisticated cardiorespiratory parameters are continuously (breath-by-breath) measured or estimated; this volume of physiological data obtained is necessary in order to assess each organ system response in coupling external respiration (i.e., oxygen uptake $\left(\mathrm{VO}_{2}\right)$ and carbon dioxide output at the airways) to cellular respiration (i.e., oxygen consumption and carbon dioxide production), during exercise. Indications of CPET include: (a) evaluation of exercise capacity, (b) evaluation and differential diagnosis of exercise intolerance, (c) evaluation of disability, (d) designing the rehabilitation program and assessing its efficacy, (e) preoperative evaluation, (f) functional and prognostic evaluation of patients with heart diseases, (g) functional and prognostic evaluation of patients with respiratory disorders, and (h) assessing treatment efficacy [25]. Commonly measured variables during CPET are presented in Table 1. 
Table 1. Commonly measured CPET variables [28]

\begin{tabular}{|c|c|}
\hline Parameter measured (units) & Definition \\
\hline $\mathrm{VO}_{2} \max ($ in $\mathrm{mL} / \mathrm{min}$ or $\mathrm{L} / \mathrm{min}$ ) & $\begin{array}{l}\text { The product of the highest } \mathrm{CO} \text { and arterial and venous } \mathrm{O}_{2} \text { content difference }(\mathrm{A}-\mathrm{V}) \mathrm{O}_{2} \text {, } \\
\mathrm{VO}_{2} \max =\mathrm{COmax} \times(\mathrm{A}-\mathrm{V}) \mathrm{O}_{2} \max \end{array}$ \\
\hline $\mathrm{VO}_{2}$ peak (in $\mathrm{mL} / \mathrm{min}$ or $\mathrm{L} / \mathrm{min}$ ) & The highest value obtained at the end of an exercise test to exhaustion \\
\hline RER & The ratio of $\mathrm{CO}_{2}$ production and $\mathrm{O}_{2}$ consumption $\left(\mathrm{VCO}_{2} / \mathrm{VO}_{2}\right)$ \\
\hline $\begin{array}{l}\text { Ventilatory equivalents for } \mathrm{O}_{2} \\
\left(\mathrm{VE} / \mathrm{VO}_{2}\right) \text { and } \mathrm{CO}_{2}\left(\mathrm{VE} / \mathrm{VCO}_{2}\right)\end{array}$ & $\begin{array}{l}\text { The ratio of pulmonary ventilation and } \mathrm{O}_{2} \text { consumption }\left(\mathrm{VE} / \mathrm{VO}_{2}\right) \text { or the ratio of pulmonary } \\
\text { ventilation and } \mathrm{CO}_{2} \text { production }\left(\mathrm{VE} / \mathrm{VCO}_{2}\right)\end{array}$ \\
\hline VE-VCO 2 slope & The relationship between $\mathrm{VE}$ (plotted in the $\mathrm{y}$-axis), and $\mathrm{VCO}_{2}$ (plotted in the $\mathrm{x}$-axis) \\
\hline $\mathrm{PETCO}_{2}($ in $\mathrm{mmHg})$ & The carbon dioxide partial pressure at the end of expiration \\
\hline $\begin{array}{l}\Delta \mathrm{VO}_{2} / \Delta \mathrm{WR} \text { relationship }\left(\mathrm{VO}_{2} \text { in }\right. \\
\mathrm{mL} / \mathrm{min} \text { and workload in watts })\end{array}$ & $\begin{array}{l}\text { It is the relationship between } \mathrm{VO}_{2} \text { and workload. It is measured during exercise on a cycle } \\
\text { ergometer with a ramp protocol }\end{array}$ \\
\hline $\begin{array}{l}\text { Respiratory reserve (VE/MVV) } \\
\text { (both VE, MVV in L/min) }\end{array}$ & It is the ratio between maximum VE and MVV assessed at rest \\
\hline IC $(\mathrm{L}$ or $\mathrm{mL})$ & It is the maximum amount of air that can be expired after a normal exhalation \\
\hline \multicolumn{2}{|c|}{$\begin{array}{l}\mathrm{CO} \text {, cardiac output; } \mathrm{CPET} \text {, cardiopulmonary exercise testing; } \mathrm{VO}_{2} \mathrm{max} \text {, maximum oxygen uptake; } \mathrm{VO}_{2} \text { peak, peak oxygen uptake; } \mathrm{RER} \text {, } \\
\text { respiratory exchange ratio; IC, inspiratory capacity; } \mathrm{AT} \text {, anaerobic threshold; } \mathrm{VT} \text {, ventilatory threshold; } \mathrm{PETCO}_{2} \text {, end-tidal } \mathrm{CO}_{2} \text { partial } \\
\text { pressure; VE, pulmonary ventilation; VE, ventilation during exercise; } \mathrm{MVV} \text {, maximum voluntary ventilation; } \mathrm{RR} \text {, respiratory rate. }\end{array}$} \\
\hline
\end{tabular}

\section{Most Commonly Used CPET Indexes}

In the following paragraphs, we briefly analyze the most important variables obtained during CPET.

\section{$\mathrm{VO}_{2}$ and Peak Oxygen Uptake}

$\mathrm{VO}_{2}$ is the volume of $\mathrm{O}_{2}$ extracted from the air inhaled during pulmonary ventilation in a period of time. It is usually expressed in $\mathrm{mL} / \mathrm{min}$ or $\mathrm{L} / \mathrm{min}$. Historically, the $\mathrm{VO}_{2}$ plateau demonstrated by a series of high intensity constant work-rate tests was used to define maximum $\mathrm{VO}_{2}\left(\mathrm{VO}_{2} \mathrm{max}\right)$, in healthy individuals. However, the flattening of the $\mathrm{VO}_{2}$-work rate relationship is often not seen during incremental exercise tests; thus, $\mathrm{VO}_{2} \mathrm{max}$ is defined as the highest $\mathrm{VO}_{2}$ attainable for a given form of exercise, as evidenced by a failure for $\mathrm{VO}_{2}$ to further increase, despite a progressive increase in work rate. In practice peak $\mathrm{VO}_{2}\left(\mathrm{VO}_{2}\right.$ peak), that is the highest value reached at the end of an exhausting exercise test, is used alternatively to $\mathrm{VO}_{2} \max$, both in healthy individuals and diseased populations [26]. Mean values at intervals of 10-
$60 \mathrm{~s}$ should be measured depending on the protocol (short-interval means for protocols with short stages and longer interval means for protocols with longer stages) $[27,28] . \mathrm{VO}_{2}$ peak is considered abnormal when below $85 \%$ of the predicted value [29]. $\mathrm{VO}_{2}$ peak has become the "gold standard" laboratory measure of cardiorespiratory fitness and the most important measurement during the functional exercise testing. It has been used as a universal marker, which can reflect disease severity in patients with heart failure, pulmonary hypertension, hypertrophic cardiomyopathy, chronic obstructive pulmonary disease, and restrictive pulmonary disease, in addition to physical fitness level [30].

\section{Anaerobic Threshold}

The anaerobic threshold (AT) (Fig. 1), also known as the lactate threshold, lactic acid threshold, or gas exchange threshold, is considered an estimator of the onset of metabolic acidosis caused predominantly by the increased rate of arterial lactate concentration during exercise. The 


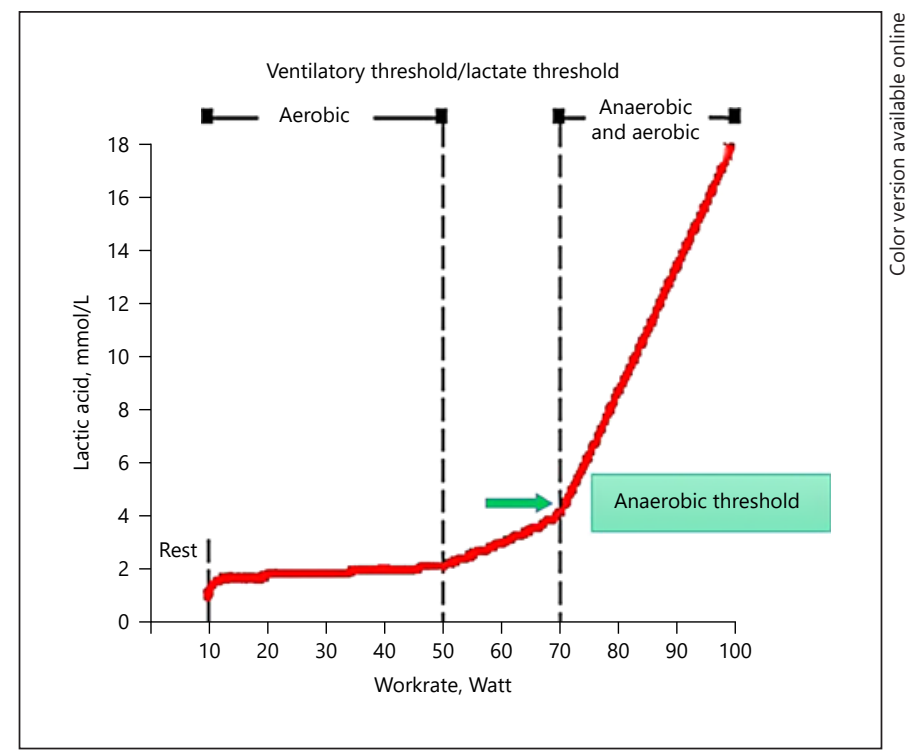

Fig. 1. Lactic acid levels during exercise testing showcasing the AT. The AT is the level of exercise $\mathrm{VO}_{2}$, above which aerobic energy production is supplemented by anaerobic mechanisms, which is reflected by an abrupt increase in the arterial lactic acid concentration. AT, anaerobic threshold.

AT is referenced to the $\mathrm{VO}_{2}$ at which this change occurs and is expressed as a percentage of the predicted value of $\mathrm{VO}_{2}$ peak ( $\% \mathrm{VO}_{2}$ peak predicted). From the physiological viewpoint, AT represents the upper limit of workloads during exercise, which can be sustained over a prolonged period of time without progressively increasing arterial blood lactate or as the level of exercise $\mathrm{VO}_{2}$ above which aerobic energy production is supplemented by anaerobic mechanisms. The normal mean AT values expected for adults are around $40-65 \%$ of peak $\mathrm{VO}_{2}$ [29]. The $\mathrm{AT}$ is calculated with the V-slope method; when $\mathrm{VCO}_{2}$ is plotted against $\mathrm{VO}_{2}$, their relationship is composed of 2 linear components, the lower of which has a slope of less than 1 and the upper has a slope steeper than 1 . The intercept of these 2 slopes is the AT [26]. The ability to achieve the AT can assist in differentiating cardiac and noncardiac causes of exercise limitation; fatigue before reaching AT is likely related to noncardiac causes [28].

\section{Respiratory Exchange Ratio}

It expresses the ratio between $\mathrm{CO}_{2}$ output and $\mathrm{O}_{2}$ uptake $\left(\mathrm{VCO}_{2} / \mathrm{VO}_{2}\right)$. It is currently the best noninvasive indicator of maximal exercise intensity. Values above 1.0 can reflect intense exercise, but those $\geq 1.10$ are those searched on CPET, and have been accepted as a parameter of maximal effort/exhaustion $[28,30]$.

\section{Methodology}

Two modes of exercise are commonly employed in CPET: treadmill and cycle ergometer, with the latter being the preferable one. Although there are many computerized systems for data collection and analysis available for the clinical laboratory, it is important that the methods used be validated, that appropriate calibration be performed, and that quality assurance be undertaken and maintained [24]. To evaluate the metabolic responses to exercise, breath-by-breath analysis techniques are used. Expired gas can be collected and analyzed via a non-rebreathing valve which allows inspired from expired gas flows to be separated and is connected to a mouthpiece or face mask. Moreover, gas analyzers are incorporated to the exercise testing system, allowing the measurement of the fraction of oxygen or carbon dioxide in the total gas [25]. The respired gas volume and flow rates are also computed during exercise, and several methods have been applied. Whereas, expired flow is usually measured and integrated into volume, physiological variables may be also calculated, with the appropriate adjustments, from inspired flow or volume [25]. Continuous 12-lead electrocardiogram (ECG) monitoring, pulse oximetry, and frequent noninvasive blood pressure measurements are required as well, during CPET. Since verbal communication is usually not possible with the mouthpiece apparatus, hand signals are usually used by the patient during exercise $[23,31]$. CPET can be performed using incremental or constant work rate protocols, according to the purpose of the test and the functional status of the patient. Importantly, the day of the test the patients are advised to adhere to their regular medication. In CKD patients, hemoglobin $(\mathrm{Hgb})$ level is an issue that should be taken under consideration. Since the oxygen-carrying capacity of the blood depends directly on the level of $\mathrm{Hgb}$, a $3 \mathrm{~g} / \mathrm{dL}$ decrease in $\mathrm{Hgb}$ concentration would result in a reduction of the total oxygen-carrying capacity by $4 \mathrm{~mL}$ per $100 \mathrm{~mL}$ blood [32]; thus, it is important when serial CPET measurements are evaluated, Hgb levels to be within recommended range.

In general, since the subject is exercising in the laboratory under close monitoring and with resuscitation measures readily available, there are only a few absolute contraindications for the conduction of CPET, even in patients with multiple comorbidities. The most important refer to acute or uncontrolled cardiovascular conditions (e.g., syncope, unstable angina, uncontrolled heart failure, acute myocardial infarction, and acute pulmonary embolism), serious cardiac dysrhythmias on resting ECG or severe respiratory failure (rest oxygen saturation, $\mathrm{sPO}_{2}$ $\leq 85 \%$ ). Severe electrolyte abnormalities and uncontrolled 


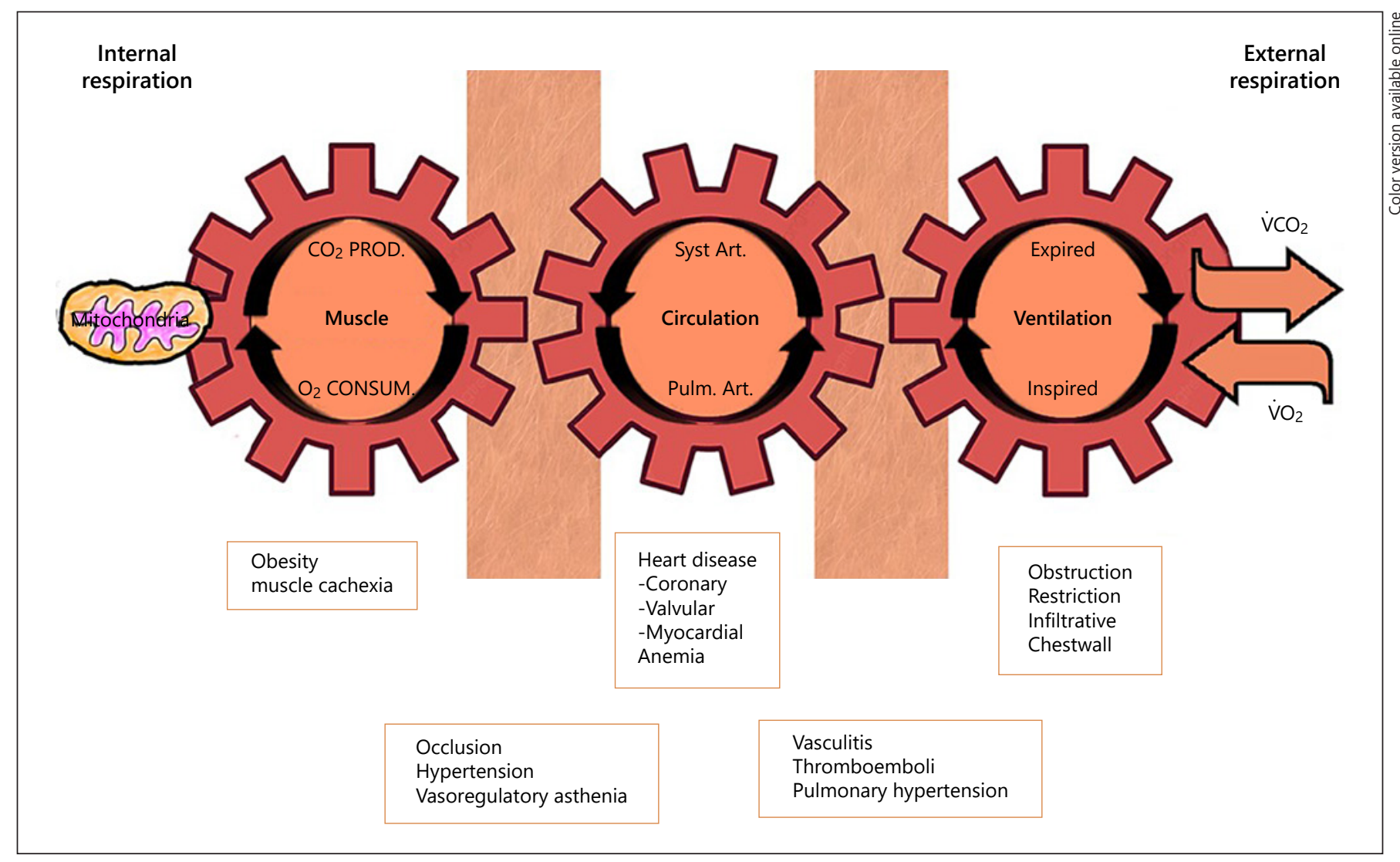

Fig. 2. The oxygen transport chain. The 3 gears represent the functional interdependence between the lungs, circulation, and muscle (modified from Wasserman, 1997 [80]). The determinants of each stage are also displayed.

hypertension at rest (>200 $\mathrm{mm} \mathrm{Hg}$ systolic, $>120 \mathrm{~mm} \mathrm{Hg}$ diastolic), which may be established among CKD patients are relative contraindications, along with severe pulmonary hypertension and serious valvular disorders. Finally, subjects with orthopedic or neurologic disorders, are also not ideal candidates for CPET [24].

CPET can be combined with invasive hemodynamic assessment, for example, radial or pulmonary arterial catheters in place, but the noninvasive (conventional) one, is the appropriate initial test to evaluate exercise intolerance [33].

\section{Physiology of Exercise and Fick Equation}

At rest, the metabolic processes of the human body are met primarily through aerobic metabolism. During activity, an increase in $\mathrm{VO}_{2}$ is required to meet the metabolic demand of the working muscle. Initially, increasing $\mathrm{VO}_{2}$ is largely dependent on the rate and amount of oxygen delivered to exercising muscle, a function of the cardiac output, oxygen carrying capacity of the blood, and vascu- lar convective transport [34]. Once oxygen is delivered to the working muscle, $\mathrm{VO}_{2}$ is dependent on oxygen utilization properties of the skeletal muscle [35] (Fig. 2). As long as the activity intensity levels remain light to moderate, aerobic metabolism effectively matches the energy demand [36]. High intensity exercise, though, is limited by the capacity of aerobic metabolism and often results in $\mathrm{VO}_{2}$ rising to its most tolerable limit, due to symptomrelated fatigue that causes the individual to stop the activity [37].

According to the Fick equation, $\mathrm{VO}_{2}$ equals cardiac output times the arterial-mixed venous oxygen content difference: $\mathrm{VO}_{2}=(\mathrm{SV} \times \mathrm{HR}) \times\left(\mathrm{CaO}_{2}-\mathrm{CvO}_{2}\right)$, where $\mathrm{VO}_{2}$ is the oxygen uptake, $\mathrm{SV}$ is the stroke volume, $\mathrm{HR}$ is heart rate, $\mathrm{CaO}_{2}$ is arterial oxygen content, and $\mathrm{CvO}_{2}$ is the mixed venous oxygen content [23]. In most cases, $\mathrm{VO}_{2}$ is normalized for body weight and expressed in $\mathrm{mL} \mathrm{O}_{2} / \mathrm{kg} / \mathrm{min}$. One metabolic equivalent is the resting $\mathrm{VO}_{2}$ in a sitting position and equals $3.5 \mathrm{~mL} / \mathrm{kg}$ per min. At maximal exercise, the Fick equation is expressed as follows: $\mathrm{VO}_{2} \max =[(\mathrm{SV} \max ) \times$ 
$(\mathrm{HRmax})] \times\left[\left(\mathrm{CaO}_{2} \max \right)-\left(\mathrm{CvO}_{2} \min \right)\right] . \mathrm{VO}_{2}$ max reflects the maximal ability of a person to take in, transport, and use oxygen; it therefore equals the functional aerobic capacity of that individual. In practice, however, $\mathrm{VO}_{2}$ peak, that is, the highest value obtained at the end of an exercise test to exhaustion, is used as $\mathrm{VO}_{2} \max [23,38]$.

\section{Exercise Intolerance}

Exercise intolerance (or decreased exercise capacity) is defined by the presence of abnormally low $\mathrm{VO}_{2}$ peak, of any cause. Based on the Fick equation, any factor that may impair maximum cardiac output (e.g., heart failure) or affect arterial or mixed venous oxygen content (e.g., diseases of the lungs, skeletal muscle dysfunction, or anemia) may result to decreased $\mathrm{VO}_{2}$ peak [23]. Furthermore, in patients with chronic respiratory disorders, mechanical constrains of ventilation is another important cause of exercise limitation, since produced respiratory discomfort may limit exercise capacity before actual physiological limitation occurs [39]. Exercise intolerance is highly prevalent in CKD and is associated with increased frailty, worsened quality of life, and high risk of hospitalization and mortality [37]. The mechanisms of exercise intolerance in CKD appear to be a complex interaction between central and peripheral factors, including kidney diseaserelated metabolic derangements, cardiac and pulmonary dysfunction, altered physiologic responses to oxygen consumption, vascular derangement, abnormal neurocirculatory control, and sarcopenia. These central and peripheral factors may result in exercise limitation, principally of circulatory etiology, via several mechanisms, such as deconditioning, anemia, uncontrolled hypertension, sarcopenia, and heart failure, creating one or more distinct CPET patterns, which permit prioritization of contributing factors. However, these abnormalities remain to be fully elucidated, particularly in the non-dialysis CKD population [37].

\section{CPET Studies in Patients with Pre-Dialysis CKD}

In previous years, various studies aimed to quantify the cardiovascular reserve of CKD patients who were not on renal replacement therapy or kidney transplanted using the CPET technology. In the following lines, existing studies using CPET in patients with non-dialysis CKD are described, categorized by type of design; observational studies, and randomized trials.

\section{Observational Studies Using CPET in Non-Dialysis CKD Patients}

A few early studies used CPET in small samples of predialysis CKD patients to evaluate exercise tolerance in association with other cardiovascular factors $[40,41]$. Observational studies with better defined design are summarized in Table 2.

\section{Studies Comparing CPET Parameters in CKD}

Patients of Various Stages with Controls

In a cross-sectional analysis, Nelson et al. [42] used CPET in $93 \mathrm{CKD}$ stage 3 patients, in comparison to 840 individuals with renal function $>60 \mathrm{~mL} / \mathrm{min} / 1.73 \mathrm{~m}^{2}$. Patients with $\mathrm{CKD}$ had lower predicted $\mathrm{VO}_{2}$ peak, lower peak heart rate, lower AT, and impaired heart rate recovery. Kirkman et al. [14] evaluated 31 patients with stage 3-5 pre-dialysis CKD and 21 age-matched healthy controls with CPET observing again that $\mathrm{VO}_{2}$ peak and $\mathrm{VO}_{2}$ at the AT $\left(\mathrm{VO}_{2} \mathrm{AT}\right)$ were lower in CKD patients compared to healthy controls. In addition, 2 studies have examined CKD patients categorized by CKD stage, showing deterioration of exercise tolerance with advancing CKD. In particular, Faria Rde et al. [43], evaluated 29 CKD patients (stages 3, 4, and 5 before dialysis) and 18 healthy controls with CPET and 6-min walking test (6MWT), observing significant deterioration of $\mathrm{VO}_{2}$ peak (controls: $28.9 \pm 7.8$, CKD stage 3: $23.3 \pm 5.6$, CKD stage 4: $21.4 \pm 5.2$, CKD stage 5: $20.2 \pm 6.9 \mathrm{~mL} /$ $\mathrm{min} / \mathrm{kg} ; p=0.03$ ) and $6 \mathrm{MWT}$ distance with advancing CKD. Similarly, Chinnappa et al. [44] evaluated with CPET 70 asymptomatic CKD patients, 35 age-matched healthy controls and 25 age-matched heart failure patients. $\mathrm{VO}_{2}$ max was lower in CKD patients than in controls but higher when compared to heart failure patients (Table 2).

Studies Examining CPET Parameters in Relation to Vascular Function Measures

Two studies $[45,46]$ investigated whether endothelial dysfunction or arterial stiffness are associated with exercise capacity in CKD patients. Van Craenenbroeck et al. [45] evaluated 63 patients with CKD divided in 2 eGFR groups, both of which displayed significantly lower $\mathrm{VO}_{2}$ peak and $\mathrm{VO}_{2} \mathrm{AT}$ (Table 2). Arterial stiffness measured with pulse wave velocity $(\beta=-0.301, p=0.01)$ and eGFR $(\beta=0.363, p=0.002)$ were independently associated with $\mathrm{VO}_{2}$ peak in multiple regression analysis. In the second study, Downey et al. [46] examined exercise capacity in $38 \mathrm{CKD}$ patients divided into 2 groups according to flow-mediated dilation (FMD) levels. Compared 
Table 2. Observational studies in pre-dialysis CKD patients using CPET

\begin{tabular}{lll}
\hline Study ID Population characteristics $\quad$ Study assessments & $\begin{array}{l}\text { Follow-up/ Results } \\
\text { time of } \\
\text { evaluation }\end{array}$ \\
\hline
\end{tabular}

Studies comparing CPET parameters in CKD patients of various stages with controls

Faria Rde 29 pre-dialytic CKD CPET 6-min walk test No follow-up

et al. [43] patients stage 3-5, Laboratory tests

9 healthy controls

alk test No follow-up CKD versus controls:

Maximal exercise tolerance (CPET)

$\left(\mathrm{VO}_{2}\right.$ peak $[\mathrm{mL} / \mathrm{kg} / \mathrm{min}]$ : stage $3: 23.3 \pm 5.6$, stage $4: 21.4 \pm 5.2$, and stage

5: $20.2 \pm 6.9$, controls: $28.9 \pm 7.8, p=0.03)$

Submaximal exercise tolerance (6-min walk test):

(Distance [m]: stage 3: $577.4 \pm 66.1$, stage 4: $542.7 \pm 57.3$, stage 5:

531.5 \pm 84.2 , controls: $627.6 \pm 37.8, p=0.01$ )

\begin{tabular}{lll}
\hline Nelson & $93 \mathrm{CKD}$ patients stage 3, & CPET \\
et al. [42] & $\begin{array}{l}840 \text { patients }(\mathrm{eGFR}>60 \\
\left.\mathrm{mL} / \mathrm{min} / 1.73 \mathrm{~m}^{2}\right)\end{array}$ & Echocardiograph
\end{tabular}

No follow-up CKD stage 3 versus controls (eGFR $>60 \mathrm{~mL} / \mathrm{min} / 1.73 \mathrm{~m}^{2}$ )

$\left.\mathrm{mL} / \mathrm{min} / 1.73 \mathrm{~m}^{2}\right)$

Lower $\mathrm{VO}_{2}$ peak (mean difference: $6 \%$ [95\% CI $\left.1-11 \%\right] ; p=0.02$ ),

Lower peak heart rate (mean difference: 9 bpm [95\% CI 3-14);

$p=0.03])$,

Lower AT (mean difference: $1.1 \mathrm{~mL} / \mathrm{min} / \mathrm{kg}$ [95\% CI 0.4-1.7];

$p<0.001)$

Lower heart rate recovery (mean difference: 4 bpm [95\% CI 1-7); $p<0.001])$

\begin{tabular}{ll}
\hline Kirkman & 31 CKD pre-dialysis \\
et al. [14] & patients stage $3-5$, \\
& 21 age matched healthy \\
& controls
\end{tabular}

CPET

No follow-up CKD versus controls:

$\mathrm{VO}_{2}$ peak: $17.43 \pm 1.03$ versus $28 \pm 2.05 \mathrm{~mL} / \mathrm{kg} / \mathrm{min} ; p<0.01$

$\mathrm{VO}_{2}$ at the ventilatory threshold: $9.44 \pm 0.53$ versus $15.55 \pm 1.34 \mathrm{~mL} / \mathrm{kg} /$ $\min ; p<0.01$

Minute ventilation rate/carbon dioxide production slope: $32 \pm 0.8$

versus $28 \pm 1 ; p<0.01$

Expired carbon dioxide pressure: $27 \pm 0.6$ versus $31 \pm 0.9$ versus 0.9 ; $p<0.01$

Ventilatory cost of $\mathrm{VO}_{2}: 37 \pm 0.8$ versus $33 \pm 1 ; p<0.01$ )

Maximum heart rate: $134 \pm 5$ versus $159 \pm 3 \mathrm{bpm}, p<0.01$

One-minute heart rate recovery: $15 \pm 1$ versus $20 \pm 2 \mathrm{bpm}, p<0.01$

\begin{tabular}{|c|c|c|c|c|}
\hline $\begin{array}{l}\text { Chinnappa } \\
\text { et al. [44] }\end{array}$ & $\begin{array}{l}70 \text { patients with CKD } \\
\text { (male, nondiabetic) } \\
21 \text { CKD 2-3a, } \\
27 \text { CKD 3b-4 and } \\
22 \text { CKD 5, pre-dialysis } \\
35 \text { age-matched healthy } \\
\text { controls } \\
25 \text { age-matched patients } \\
\text { with heart failure }\end{array}$ & CPET & No follow-up & $\begin{array}{l}\text { CKD versus healthy controls: } \\
\mathrm{VO}_{2} \mathrm{max}(\mathrm{mL} / \mathrm{min} / \mathrm{kg})(\mathrm{CKD} 2-3 \mathrm{a}: 33.5 \pm 6.5, \mathrm{CKD} 3 \mathrm{~b}-4: 29.9 \pm 5.5 \text {, } \\
\mathrm{CKD} 5: 24.9 \pm 3.5 \text {, controls: } 37.7 \pm 7.8, p<0.005) \\
\text { Peak cardiac power (watt) (CKD 2-3a: } 5.02 \pm 0.78 \text {, CKD } 3 \mathrm{~b}-4: \\
4.59 \pm 0.53 \text {, CKD 5: } 4.02 \pm 0.73 \text {, controls: } 6.13 \pm 1.11, p<0.005) \\
\text { CKD versus heart failure patients: } \\
\mathrm{VO}_{2} \mathrm{max}(\mathrm{mL} / \mathrm{min} / \mathrm{kg} \text { ) (CKD 2-3a: } 33.5 \pm 6.5 \text {, CKD 3b-4: } 29.9 \pm 5.5 \text {, } \\
\mathrm{CKD} 5: 24.9 \pm 3.5 \text {, heart failure: } 19.9 \pm 3.9, p<0.005) \\
\text { Peak cardiac power (Watt) (CKD } 2-3 \mathrm{a}: 5.02 \pm 0.78, \mathrm{CKD} 3 \mathrm{~b}-4: \\
4.59 \pm 0.53, \mathrm{CKD} 5: 4.02 \pm 0.73 \text {, heart failure: } 2.34 \pm 0.63, p<0.005)\end{array}$ \\
\hline \multicolumn{5}{|c|}{ Studies examining CPET parameters in relation to vascular function measures } \\
\hline $\begin{array}{l}\text { Van } \\
\text { Craenenbroeck } \\
\text { et al. }[45]\end{array}$ & $\begin{array}{l}63 \text { patients with CKD } \\
\text { stage } 1-5 \\
\text { eGFR }>45 \mathrm{~mL} / \mathrm{min} / \\
1.73 \mathrm{~m}^{2}: 32 \\
\text { eGFR }<45 \mathrm{~mL} / \mathrm{min} / \\
1.73 \mathrm{~m}^{2}: 31 \\
18 \text { healthy controls }\end{array}$ & $\begin{array}{l}\text { CPET } \\
\text { Vascular assessment } \\
\text { (Endothelial- } \\
\text { dependent } \\
\text { vasodilation, Arterial } \\
\text { stiffness, Targeted } \\
\text { quantification of } \\
\text { miRNA) }\end{array}$ & No follow-up & 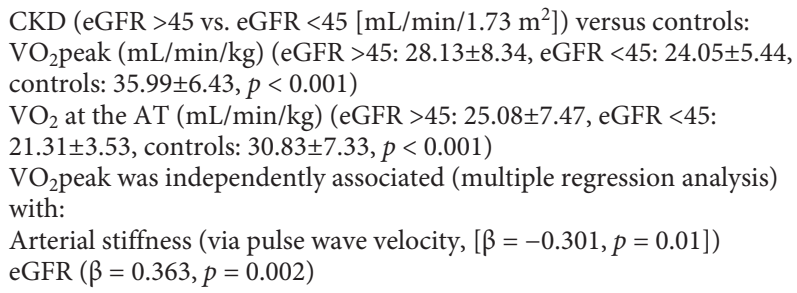 \\
\hline $\begin{array}{l}\text { Downey } \\
\text { et al. [46] }\end{array}$ & $\begin{array}{l}38 \text { patients with } \mathrm{CKD} \\
\text { stage } 2-3 \text {, } \\
21 \text { healthy controls }\end{array}$ & $\begin{array}{l}\text { CPET } \\
\text { FMD }\end{array}$ & No follow-up & $\begin{array}{l}\text { CKD versus healthy controls: } \\
\left.\mathrm{VO}_{2} \text { peak (mL/min/kg) (CKD: } 22 \pm 1 \text {, controls: } 30 \pm 2, p<0.001\right) \\
\text { Maximum diastolic BP during CPET (mm Hg) (CKD: } 88 \pm 2 \text {, controls: } \\
82 \pm 2, p=0.015 \text { ) } \\
\text { Among CKD patients ([low FMD group] versus [high FMD group]) } \\
\left.\left.\mathrm{VO}_{2} \text { peak (mL/min } / \mathrm{kg}\right) \text { : low: } 19.47 \pm 1.47 \text {, high: } 24.57 \pm 1.51, p<0.001\right)\end{array}$ \\
\hline \multicolumn{5}{|c|}{ Studies examining the efficacy of exercise programs } \\
\hline $\begin{array}{l}\text { Hama } \\
\text { et al. [47] }\end{array}$ & $\begin{array}{l}86 \text { patients with CKD } \\
\text { stage } 3-4\end{array}$ & CPET & $\begin{array}{l}\text { Follow-up: } \\
3 \text { months }\end{array}$ & $\begin{array}{l}\text { Before versus after rehabilitation: } \\
\mathrm{VO}_{2} \text { peak }(\mathrm{mL} / \mathrm{min} / \mathrm{kg}) \text { : before: } 15.0 \pm 3 \text {, after: } 15.8 \pm 3, \mathrm{p}=0.002 \\
\text { Peak work rate (Watt): before: } 65.5 \pm 21 \text {, after: } 70.2 \pm 25, \mathrm{p}=0.001 \text {. }\end{array}$ \\
\hline
\end{tabular}


Table 2 (continued)

\begin{tabular}{|c|c|c|c|c|}
\hline Study ID & Population characteristics & Study assessments & $\begin{array}{l}\text { Follow-up/ } \\
\text { time of } \\
\text { evaluation }\end{array}$ & Results \\
\hline $\begin{array}{l}\text { Wilkinson } \\
\text { et al. [12] }\end{array}$ & $\begin{array}{l}32 \text { patients with pre- } \\
\text { dialysis CKD stage } 3 \mathrm{~b}-5 \\
\text { (not-dialysis) }\end{array}$ & CPET & $\begin{array}{l}\text { Follow-up: } \\
12 \text { weeks }\end{array}$ & $\begin{array}{l}\text { Before versus after exercise training program: } \\
\text { No meaningful changes in any other cardiorespiratory value obtained } \\
\left(\mathrm{VO}_{2} \text { peak; } p=0.602, \text { Peak minute ventilation }[\mathrm{VE}] / \mathrm{VO}_{2} ;\right. \\
p=0.853 \text {, Peak VE; } p=0.095 \text {, Peak respiratory exchange ratio [RER]; } \\
p=0.864) \\
\text { OUES calculated at } 100 \%, 90 \%, 75 \% \text {, and } 50 \% \text { of exercise duration did } \\
\text { not change after } 12 \text { weeks of exercise training }(p=0.642, p=0.250, p= \\
0.196 \text { and } p=0.869 \text {, respectively) }\end{array}$ \\
\hline \multicolumn{5}{|c|}{ Studies examining the reproducibility } \\
\hline $\begin{array}{l}\text { Wilkinson } \\
\text { et al. [48] }\end{array}$ & $\begin{array}{l}41 \text { patients with pre- } \\
\text { dialysis CKD stage } 3 \mathrm{~b}-5\end{array}$ & $\begin{array}{l}\text { CPET } \\
\text { ISWT } \\
\text { STS } \\
\text { e1RM }\end{array}$ & $\begin{array}{l}\text { Follow-up: } \\
6 \text { weeks }\end{array}$ & $\begin{array}{l}\text { ISWT, STS-60, e1RM, and CPET: intraclass correlation coefficient }{ }^{\circledR} \\
\text { values of } 0.973,0.927,0.927 \text {, and } 0.86 \text {, respectively } \\
\text { ISWT and } \mathrm{VO}_{2} \text { peak: strong correlation }(r=0.73 \text { and } 0.74)\end{array}$ \\
\hline
\end{tabular}

CPET, cardiopulmonary exercise testing; $\mathrm{CKD}$, chronic kidney disease; $\mathrm{VO}_{2}$, oxygen uptake; $\mathrm{VO}_{2}$ peak, peak oxygen uptake; AT, anaerobic threshold; bpm, beats per minute; CI, confidence interval; miRNA, microRNA; eGFR, estimated glomerular filtration rate; FMD, flow-mediated dilation; ISWT, incremental shuttle walk test; STS, "sit-to-stand" test; e1RM, estimated 1 repetition maximum for quadriceps strength; OUES, oxygen uptake efficiency slope; VE, ventilation.

with patients at the high group (equal to or higher than the common median FMD value of $2.95 \%$ ), these at the low FMD (lower than the common median FMD value) had significantly poorer exercise capacity.

Studies Examining the Efficacy of Exercise Programs

Among studies evaluating the efficacy of rehabilitation programs, a retrospective post hoc analysis of a clinical trial [47] in which CPET was performed at the beginning and end of a 3-month cardiac rehabilitation program evaluated 86 patients with CKD stage 3-4, who were hospitalized for cardiovascular disease-related events. Both $\mathrm{VO}_{2}$ peak and the work rate improved significantly after cardiac rehabilitation. Another study [12] included $32 \mathrm{pa}-$ tients with CKD 3b-5 (not requiring dialysis), in which CPET was performed at baseline, following a 12-week exercise training program and after a 6 -week non-exercise period. The study evaluated the $\mathrm{VO}_{2}$ efficiency slope that represents the relationship between $\mathrm{VO}_{2}$ and total ventilation, providing an indication of cardiorespiratory reserve. The $\mathrm{VO}_{2}$ efficiency slope calculated at $100 \%, 90 \%$, $75 \%$, and $50 \%$ of exercise duration did not change significantly after 12 weeks of exercise training; similarly, no meaningful changes were observed following the exercise program in all other cardiorespiratory parameters examined (Table 2).

\section{Studies Examining the Reproducibility of CPET}

\section{Testing}

Wilkinson et al. [48] tried to determine the reliability and the estimated minimal detectable change of CPET and other physical function tests in 41 patients with pre-dialysis CKD. Assessments were performed at 2 time points (test 1 and 2) separated by a 6-week period in which patients were instructed to maintain their habitual lifestyle. There was minimal difference between the 2 CPET tests (intraclass correlation coefficient $[r] 0.866$ ) and all the other tests examined, with the exception of sit-to-stand test-5.

\section{Randomized Trials Using CPET in Non-Dialysis CKD Patients}

All randomized trials using CPET in patients with predialysis CKD have studied the effects of programs of exercise training. Among these trials, summarized in Table 3, several suggest significant improvement of physical performance of CKD patients following exercise interventions. The earliest of positive studies which showed significantly improved $\mathrm{VO}_{2}$ peak and endurance time in the exercise group, randomized 20 pre-dialysis CKD patients in a 12-month exercise program or standard care [49]. Several studies in pre-dialysis CKD patients of various stages with populations ranging from 11 to 142 patients and study duration up to 12 months have shown beneficial effects of various exercise programs on $\mathrm{VO}_{2}$ peak and other CPET parameters [49-62]. In some cases, more than one type of exercise training were examined; for example, 
Table 3. Randomized trials in pre-dialysis CKD patients using CPET

\begin{tabular}{|c|c|c|c|c|}
\hline Study ID & Population characteristics & Study assessments & $\begin{array}{l}\text { Follow-up/ } \\
\text { time of } \\
\text { evaluation }\end{array}$ & Results \\
\hline $\begin{array}{l}\text { Eidemak et al. } \\
{[63]}\end{array}$ & $\begin{array}{l}30 \text { CKD patients (GFR: } \\
25 \mathrm{~mL} / \mathrm{min} / 1.73 \mathrm{~m}^{2} \text { ) } \\
\text { (randomized to: } \\
\text { Physical training: } 15 \\
\text { Maintenance of the usual } \\
\text { lifestyle: } 15 \text { ) }\end{array}$ & $\begin{array}{l}\text { CPET } \\
\text { Blood tests }\end{array}$ & $\begin{array}{l}\text { Follow-up: } \\
18 \text { months for the } \\
\text { exercise group } \\
20 \text { months for the } \\
\text { control group }\end{array}$ & $\begin{array}{l}\text { After training intervention: (exercise group versus usual } \\
\text { lifestyle group:) } \\
\mathrm{VO}_{2} \text { peak (mL/min/kg); exercise: } 25[13-43] \text {, usual } \\
\text { lifestyle: } 21[14-40], p=\text { not significant } \\
\text { GFR, lipid concentration: no significant differences }\end{array}$ \\
\hline Leehey et al. [50] & $\begin{array}{l}11 \text { patients with CKD stage } \\
2-4 \text { ([eGFR]: } 15-90 \mathrm{~mL} / \\
\text { min/1.73 } \mathrm{m}^{2} \text { with persistent } \\
\text { proteinuria), type } 2 \text { diabetes } \\
\text { and obesity (BMI }>30 \mathrm{~kg} / \mathrm{m}^{2} \text { ) } \\
\text { (randomized to: } \\
24 \text { weeks of exercise group: } 7 \\
\text { Control group: } 4 \text { ) }\end{array}$ & $\begin{array}{l}\text { CPET } \\
\text { Nutritional and body } \\
\text { composition assessment } \\
\text { Laboratory assessments }\end{array}$ & $\begin{array}{l}\text { Follow-up: } \\
\text { 6, } 24 \text { weeks }\end{array}$ & $\begin{array}{l}\text { Baseline versus 24-week intervention (exercise group): } \\
\text { Exercise duration (min) (baseline: } 6.6 \pm 2.2 \text {, after } \\
\text { intervention: } 10.2 \pm 2.8) \\
\mathrm{VO}_{2} \mathrm{max}(\mathrm{mL} / \mathrm{min} / \mathrm{kg}) \text { (baseline: } 14.9 \pm 1.1 \text {, after } \\
\text { intervention: } 15.6 \pm 2.4) \\
\text { Resting systolic blood pressure ( } \mathrm{mm} \mathrm{Hg} \text { ) (baseline: } \\
130 \pm 28 \text {, after intervention: } 113 \pm 16) \\
\text { Urine protein excretion (mg/24 h) (baseline: } \\
1,020 \pm 1,081 \text {, after intervention: } 821 \pm 1,010) \\
\text { No significance between-groups effects over time for } \\
\text { exercise duration, oxygen consumption at "isotime," } \\
\text { blood pressure, or } 24 \text {-h proteinuria, probably due to the } \\
\text { small sample size }\end{array}$ \\
\hline $\begin{array}{l}\text { Mustata et al. } \\
\text { [49] }\end{array}$ & $\begin{array}{l}20 \text { pre-dialysis CKD patients } \\
\text { (randomized to: } \\
12 \text { months of exercise: } 10 \\
\text { Standard care: } 10 \text { ) }\end{array}$ & $\begin{array}{l}\text { CPET } \\
\text { Arterial stiffness }\end{array}$ & $\begin{array}{l}\text { Follow-up: } \\
12 \text { months }\end{array}$ & $\begin{array}{l}\text { After exercise intervention: (difference between exercise } \\
\text { group versus standard care group:) } \\
\mathrm{VO}_{2} \text { peak }(\mathrm{mL} / \mathrm{min} / \mathrm{kg})(+3.59 ; 95 \% \mathrm{CI}[0.92,6.26] ; \\
p=0.01) \\
\text { Endurance time }(\mathrm{min})(+10.97 ; 95 \% \mathrm{CI}[4.34,17.59] ; \\
p=0.003) \\
\text { Augmentation index }(-11.7 \% ; 95 \% \mathrm{CI}[-18.79,-4.61] ; \\
p=0.003)\end{array}$ \\
\hline $\begin{array}{l}\text { Headley et al. } \\
{[51]}\end{array}$ & $\begin{array}{l}21 \text { patients with CKD stage } \\
2-4 \text { (randomized to: } \\
\text { Training group: } 10 \\
\text { The usual care group: } 11 \text { ) }\end{array}$ & $\begin{array}{l}\text { CPET } \\
\text { Laboratory assessments }\end{array}$ & $\begin{array}{l}\text { Follow-up: } \\
\text { 24, } 48 \text { weeks }\end{array}$ & $\begin{array}{l}\text { Baseline versus } 48 \text {-week intervention (training group): } \\
\mathrm{VO}_{2} \text { peak }(\mathrm{mL} / \mathrm{min} / \mathrm{kg}) \text { (baseline: } 18.1 \pm 7.8 \text {, after } \\
\text { intervention: } 19.5 \pm 4.6, p<0.05) \\
\text { Reduction in both resting and ambulatory heart rate } \\
\text { Increase in LDL cholesterol }\end{array}$ \\
\hline $\begin{array}{l}\text { Howden et al. } \\
{[52]}\end{array}$ & $\begin{array}{l}72 \text { patients with CKD stage } \\
3-4 \text { (randomized to: } \\
\text { Lifestyle intervention group: } \\
36 \\
\text { Control group: } 36)\end{array}$ & $\begin{array}{l}\text { CPET } \\
\text { Biochemical analyses } \\
\text { Echocardiography } \\
\text { Arterial compliance } \\
\text { Dietary assessment }\end{array}$ & $\begin{array}{l}\text { Follow-up: } \\
12 \text { months }\end{array}$ & $\begin{array}{l}\text { Baseline versus } 12 \text { months intervention: (intervention } \\
\text { group) } \\
\mathrm{VO}_{2} \text { peak }(\mathrm{mL} / \mathrm{kg} / \mathrm{min}) \text { (difference from baseline: } \\
+2.8 \pm 0.7 ; p=0.01) \\
\text { Weight loss }(\mathrm{kg}) \text { (difference from baseline: }-1.8 \pm 4.2 ; \\
p=0.02) \\
\mathrm{BP} \text { or lipid concentration: no change } \\
\text { Diastolic function improved }(p=0.001) \text { but systolic } \\
\text { function did not change }\end{array}$ \\
\hline $\begin{array}{l}\text { Headley et al. } \\
{[53]^{\mathrm{a}}} \\
\text { Headley et al. } \\
{[54]^{\mathrm{a}}} \\
\text { Miele et al. }[55]^{\mathrm{a}}\end{array}$ & $\begin{array}{l}46 \text { patients with CKD } \\
\text { MDRD-eGFR: } 30-59 \mathrm{~mL} / \\
\text { min/ } 1.73 \mathrm{~m}^{2} \text { (diabetes or } \\
\text { hypertension as the primary } \\
\text { cause of CKD) (randomized } \\
\text { to: } \\
\text { Treatment group: } 25 \\
\text { Control group: } 21 \text { ) }\end{array}$ & $\begin{array}{l}\text { CPET } \\
\text { Arterial stiffness } \\
\text { Blood tests } \\
\text { Health-related quality of } \\
\text { life } \\
\text { 24-h ambulatory blood } \\
\text { pressure monitoring } \\
\text { Dietary assessment }\end{array}$ & $\begin{array}{l}\text { Follow-up: } \\
\text { 8, } 16 \text { weeks }\end{array}$ & $\begin{array}{l}\text { Baseline versus } 16 \text {-week intervention (exercise group) } \\
\mathrm{VO}_{2} \text { peak ( } \mathrm{mL} / \mathrm{min} / \mathrm{kg} \text { ) (baseline: } 19.6 \pm 6.7 \text {, after } \\
\text { intervention: } 21.2 \pm 7.7, p=0.05) \\
\text { (control group) } \\
\mathrm{VO}_{2} \text { peak }(\mathrm{mL} / \mathrm{min} / \mathrm{kg}) \text { (baseline: } 18.0 \pm 6.0 \text {, after } \\
\text { intervention: } 17.5 \pm 5.7) \\
\text { Aortic pulse wave velocity: no changes } \\
\text { Post-exercise hypotension occurred at baseline } \\
\text { Lower TC ( } p=0.051) \text { and LDL-C }(p=0.07) \\
\text { HDL-C, TGs, and HDL particle size and body } \\
\text { composition remained unchanged in both groups }\end{array}$ \\
\hline $\begin{array}{l}\text { Greenwood et al. } \\
{[56]}\end{array}$ & $\begin{array}{l}20 \text { patients with CKD stage } \\
\text { 3-4 (randomized to: } \\
\text { Rehabilitation: } 10 \\
\text { Usual care: } 10 \text { ) }\end{array}$ & $\begin{array}{l}\text { CPET } \\
\text { Arterial stiffness } \\
\text { Blood tests }\end{array}$ & $\begin{array}{l}\text { Follow-up: } \\
6,12 \text { months }\end{array}$ & $\begin{array}{l}\text { After rehabilitation: (Rehabilitation versus usual care } \\
\text { group) } \\
\mathrm{VO}_{2} \text { peak }(\mathrm{mL} / \mathrm{min} / \mathrm{kg}) \text { (between group mean difference: } \\
+5.7[95 \% \mathrm{CI}, 1.34-10.10], p<0.01) \\
\text { Pulse wave Velocity }(\mathrm{m} / \mathrm{s}) \text { (between group mean } \\
\text { difference: }-2.30[95 \% \mathrm{CI},-3.02 \text { to }-1.59], p<0.001) \\
\text { Waist circumference }(\mathrm{cm})(\text { between group mean } \\
\text { difference: }-7.1 \pm 12.8[95 \% \mathrm{CI},-12.4 \text { to }-3.2], p<0.003 \text { ) }\end{array}$ \\
\hline
\end{tabular}


Table 3 (continued)

\begin{tabular}{|c|c|c|c|c|}
\hline Study ID & Population characteristics & Study assessments & $\begin{array}{l}\text { Follow-up/ } \\
\text { time of } \\
\text { evaluation }\end{array}$ & Results \\
\hline Aoike et al. [57] & $\begin{array}{l}29 \text { overweight patients with } \\
\text { CKD stage } 3-4 \text { (randomized } \\
\text { to: } \\
\text { Home-based exercise group: } \\
14 \\
\text { Non exercise control group: } \\
15 \text { ) }\end{array}$ & $\begin{array}{l}\text { CPET } \\
\text { Functional capacity tests } \\
\text { (6-min walk test, 2-min } \\
\text { step test, sit-to-stand test, } \\
\text { arm curl test, sit and } \\
\text { reach test, back scratch } \\
\text { test, time up, and go test) } \\
\text { Laboratory data } \\
\text { Blood pressure } \\
\text { measurement } \\
\text { PSQI } \\
\text { DEXA }\end{array}$ & $\begin{array}{l}\text { Follow-up: } \\
12 \text { weeks }\end{array}$ & $\begin{array}{l}\text { Baseline versus } 12 \text {-week intervention group (exercise } \\
\text { group) (CPET) } \\
\text { Maximal ventilation }(\mathrm{L} / \mathrm{min}) \text { (baseline: } 77.5 \pm 25.6 \text {, after } \\
\text { intervention: } 90.7 \pm 28.1, p=0.003 \text { ) } \\
\mathrm{VO}_{2} \text { peak ( } \mathrm{mL} / \mathrm{min} / \mathrm{kg} \text { ) (baseline: } 24.1 \pm 7.1 \text {, after } \\
\text { intervention: } 26.1 \pm 7.0, p<0.05 \text { within group, no } \\
\text { significant group by time interactions) } \\
\mathrm{VO}_{2} \text { in } \mathrm{VT} \text { (mL/kg/min) (baseline: } 14.6 \pm 2.6 \text {, after } \\
\text { intervention: } 16.6 \pm 3.6, p=0.154) \\
\text { Baseline versus } 12 \text {-week intervention group (exercise } \\
\text { group) (other functional capacity tests) } \\
\text { Improvement: }(6-\text { min walk test }[p<0.001] \text {, time up and } \\
\text { go test }[p<0.001] \text {, arm curl test }[p<0.001] \text {, sit and } \\
\text { stand test }[p<0.001], 2 \text {-min step test }[p<0.001] \text {, and } \\
\text { back scratch test }[p=0.042] \text { ) }\end{array}$ \\
\hline $\begin{array}{l}\text { Van } \\
\text { Craenenbroeck } \\
\text { et al. }[58]\end{array}$ & $\begin{array}{l}40 \text { patients with CKD stage } \\
3-4 \text { without established } \\
\text { cardiovascular disease } \\
\text { (randomized to: } \\
\text { Exercise training: } 19 \\
\text { Usual care: } 21 \text { ) }\end{array}$ & $\begin{array}{l}\text { CPET } \\
\text { Endothelial function } \\
\text { Arterial stiffness } \\
\text { Cellular markers for } \\
\text { vascular function } \\
\text { Laboratory test } \\
\text { Health-related quality of } \\
\text { life }\end{array}$ & $\begin{array}{l}\text { Follow-up: } \\
3 \text { months }\end{array}$ & $\begin{array}{l}\text { Baseline versus } 3 \text {-month intervention (training group) } \\
\mathrm{VO}_{2} \text { peak ( } \mathrm{mL} / \mathrm{kg} / \mathrm{min} \text { ) (baseline: } 26.5 \pm 5.4 \text {, Intervention: } \\
32.3 \pm 6.8, p<0.001 \text { ) } \\
\text { Vascular function (FMD and carotid-femoral pulse } \\
\text { wave velocity) and cellular markers for vascular } \\
\text { function: no significant changes }\end{array}$ \\
\hline Leehey et al. [64] & $\begin{array}{l}36 \text { patients with CKD stages } \\
2-4 \text {, and persistent proteinuria } \\
(>200 \mathrm{mg} / \mathrm{g} \text { creatinine for }>3 \\
\text { months), type } 2 \text { diabetes and } \\
\text { BMI }>30 \mathrm{~kg} / \mathrm{m}^{2} \text { (randomized } \\
\text { to: } \\
\text { Exercise \& diet management: } \\
18 \\
\text { Diet management: } 18 \text { ) }\end{array}$ & $\begin{array}{l}\text { CPET } \\
\text { 6-minute walk test } \\
\text { Timed up and go test } \\
\text { Peripheral muscle } \\
\text { strength test } \\
\text { Questionnaires } \\
\text { Body composition } \\
\text { assessment } \\
\text { Laboratory tests }\end{array}$ & $\begin{array}{l}\text { Follow-up: } \\
\text { 12, } 52 \text { weeks }\end{array}$ & $\begin{array}{l}\text { Baseline versus } 12 \text {-week versus } 52 \text {-week intervention } \\
\text { (exercise and diet group) } \\
\text { Changes in treadmill times: significantly higher at } 12 \\
\text { weeks but not at } 52 \text { weeks (diet-alone group) } \\
\text { Change from baseline in urine protein to creatinine } \\
\text { ratio: slightly greater at } 12 \text { weeks but not at } 52 \text { weeks } \\
\text { No differences in } \mathrm{VO}_{2} \text { peak between the groups at either } \\
12 \text { or } 52 \text { weeks }\end{array}$ \\
\hline Aoike et al. [59] & $\begin{array}{l}40 \text { overweight patients with } \\
\text { CKD stage } 3-4 \text { (randomized } \\
\text { to: } \\
\text { Home-based exercise group: } \\
12 \\
\text { Center-based exercise group: } \\
13 \\
\text { Non exercise control group: } \\
15 \text { ) }\end{array}$ & $\begin{array}{l}\text { CPET } \\
\text { Functional capacity } \\
\text { tests (6-min walk test, } \\
\text { 2-min step test, sit-to- } \\
\text { stand test, arm curl test, } \\
\text { sit and reach test, time up } \\
\text { and go test) } \\
\text { Laboratory data } \\
\text { Blood pressure } \\
\text { measurement } \\
\text { PSQI } \\
\text { Quality of life assessment }\end{array}$ & $\begin{array}{l}\text { Follow-up: } \\
\text { 12, } 24 \text { weeks }\end{array}$ & $\begin{array}{l}\text { Home-based versus center-based exercise group: } \\
(\mathrm{CPET}) \\
\mathrm{VO}_{2} \text { peak and all cardiopulmonary parameters evaluated } \\
\text { were similarly improved }(p<0.05) \text { after } 12 \text { and } 24 \text { weeks } \\
\text { in both exercise groups (Functional capacity tests) } \\
\text { Home-based group: all improved during the follow-up } \\
\text { in the home-based group }(p<0.05) \text { and reached values } \\
\text { similar to those obtained in the center-based group. } \\
\text { The benefits achieved in both exercise groups were also } \\
\text { reflected in improvement of quality of life and sleep } \\
(p<0.05)\end{array}$ \\
\hline Ikizler et al. [65] & $\begin{array}{l}111 \text { patients with CKD (mean } \\
\text { eGFRcysC: } 41 \pm 18.6 \mathrm{mg} / \\
\text { mL/1.73 } \mathrm{m}^{2} \text { ) (randomized to: } \\
\text { Aerobic exercise and calorie } \\
\text { restriction: } 30 \\
\text { Usual activity and calorie } \\
\text { restriction: } 28 \\
\text { Aerobic exercise and usual } \\
\text { diet: } 27 \\
\text { Usual activity and usual diet: } \\
26 \text { ) }\end{array}$ & $\begin{array}{l}\text { CPET } \\
\text { Body composition } \\
\text { assessment } \\
\text { Laboratory tests }\end{array}$ & $\begin{array}{l}\text { Follow-up: } \\
2,4 \text { months }\end{array}$ & $\begin{array}{l}\text { Cardiorespiratory fitness } \\
\text { No statistically significant changes in } \mathrm{VO}_{2} \text { peak versus } \\
\text { usual care ( } p=0.43 \text { for overall treatment effect vs. usual } \\
\text { care; } p=0.56 \text { for caloric restriction vs. usual diet; } \\
p=0.37 \text { for exercise vs. usual activity) } \\
\text { Body composition } \\
\text { Decrease in body weight with intervention versus usual } \\
\text { care ( } p=0.02 \text { vs. usual care) } \\
\text { Most pronounced with caloric restriction ( } p=0.004 \text { vs. } \\
\text { usual diet) but was not among patients who received } \\
\text { exercise intervention } \\
\text { Similar effect on BMI Oxidative stress and } \\
\text { Inflammatory markers } \\
\text { The combined intervention and each independent } \\
\text { intervention led to significant decreases in } \\
\text { F2-isoprostane and IL- } 6 \text { concentrations }\end{array}$ \\
\hline
\end{tabular}


Table 3 (continued)

\begin{tabular}{|c|c|c|c|c|}
\hline Study ID & Population characteristics & Study assessments & $\begin{array}{l}\text { Follow-up/ } \\
\text { time of } \\
\text { evaluation }\end{array}$ & Results \\
\hline $\begin{array}{l}\text { Kirkman et al. } \\
{[60]}\end{array}$ & $\begin{array}{l}36 \text { non-dialysis CKD patients } \\
\text { (eGFR: } 44 \pm 2 \mathrm{~mL} / \mathrm{min} / 1.73 \mathrm{~m}^{2} \text { ) } \\
\text { (randomized to: } \\
\text { Exercise group: } 19 \\
\text { Control group: } 17 \text { ) }\end{array}$ & $\begin{array}{l}\text { CPET } \\
\text { Microvascular function } \\
\text { Conduit artery } \\
\text { endothelial function } \\
\text { Central hemodynamics } \\
\text { and arterial stiffness } \\
\text { Laboratory tests }\end{array}$ & $\begin{array}{l}\text { Follow-up: } \\
12 \text { weeks }\end{array}$ & $\begin{array}{l}\text { Baseline versus exercise training } \\
\text { Cardiorespiratory fitness } \mathrm{VO}_{2} \text { peak }(\mathrm{mL} / \mathrm{min} / \mathrm{kg} \text { ): } \\
\text { Exercise group (baseline: } 17.89 \pm 1.21 \text {, after } 12 \text { weeks: } \\
19.98 \pm 1.59, p=0.04) \\
\text { Control group (baseline: } 18.29 \pm 1.73 \text {, after } 12 \text { weeks: } \\
17.36 \pm 1.60, p=0.10 \text { ) } \\
\text { Microvascular function: } \\
\text { Exercise group: (baseline: } 87 \pm 2 \% \text {, after } 12 \text { weeks: } \\
91 \pm 2 \%, p=0.03 \text { ) } \\
\text { Control group: (baseline: } 86 \pm 2 \% \text {, after } 12 \text { weeks: } 84 \pm 3 \% \text {, } \\
p=0.03 \text { ) } \\
\text { Brachial artery FMD: } \\
\text { Exercise group: (baseline: } 2.6 \pm 0.4 \% \text {, after } 12 \text { weeks: } \\
3.8 \pm 0.8 \%, p=0.02 \text { ) } \\
\text { Control group: (baseline: } 3.5 \pm 0.6 \% \text {, after } 12 \text { weeks: } \\
2.3 \pm 0.4 \%, p=0.02)\end{array}$ \\
\hline $\begin{array}{l}\text { Beetham et al. } \\
\text { [61] }\end{array}$ & $\begin{array}{l}142 \text { patients with CKD stage } \\
\text { 3-4 (randomized to: } \\
\text { Exercise group: } 74 \\
\text { Control group: } 68 \text { ) }\end{array}$ & $\begin{array}{l}\text { CPET } \\
\text { 6-minute walking test } \\
\text { eGFR measurements } \\
\text { (MDRDcr, CKD-EPIcr, } \\
\text { CKD-EPIcys, and CKD- } \\
\text { EPIcr-cys) } \\
\text { Questionnaires } \\
\text { DEXA }\end{array}$ & $\begin{array}{l}\text { Follow-up: } \\
12 \text { months }\end{array}$ & $\begin{array}{l}\text { Fitness measures } \\
\mathrm{VO}_{2} \text { peak (mL/min/kg) } \\
\text { Exercise group: difference (after } 12 \text { months-baseline): } \\
+1.7 \pm 3.7, p<0.01 \\
\text { Control group: difference (after } 12 \text { months-baseline): } \\
-0.9 \pm 4.2, p<0.01 \\
\text { Peak MET tasks } \\
\text { Exercise group: the lifestyle intervention resulted in } \\
\text { improvement in exercise capacity ( }+1.9 \pm 1.8 \text { METs, } \\
p<0.001 \text { ) } \\
\text { No changes in lean mass in both control and exercise } \\
\text { groups during the } 12 \text { months eGFR measurements }(\mathrm{mL} / \\
\left.\text { min/1.73 } \mathrm{m}^{2}\right) \text { : CKD-EPIcy was lower in both groups at } \\
\text { both baseline and } 12 \text { months than in CKD-EPIcr, CKD- } \\
\text { EPIcr-cys, and MDRDcr }\end{array}$ \\
\hline $\begin{array}{l}\text { Beetham et al. } \\
{[62]}\end{array}$ & $\begin{array}{l}14 \text { patients with CKD stage } \\
3-4 \text { (randomized to: } \\
\text { High-intensity interval } \\
\text { training: } 9 \\
\text { Moderate-intensity } \\
\text { continuous training: } 5 \text { ) }\end{array}$ & $\begin{array}{l}\text { CPET } \\
\text { Muscle biopsy } \\
\text { Body composition } \\
\text { assessment } \\
\text { Blood tests } \\
\text { Hemodynamics } \\
\text { assessment }\end{array}$ & $\begin{array}{l}\text { Follow-up: } \\
12 \text { weeks }\end{array}$ & $\begin{array}{l}\text { High-intensity interval versus moderate-intensity } \\
\text { continuous training group } \\
\text { Number of training sessions (high-: } 33 \pm 7 \text {, moderate- } \\
\text { intensity: } 33.5 \pm 3.3 \text { ) } \\
\text { Change in exercise capacity (MET) (high-: }+0.8 \pm 1.2 \text {, } \\
\text { moderate-intensity: }+1.3 \pm 1.6, p=0.01 \text { ) } \\
\text { Change in muscle protein synthesis (high-: }+0.6 \pm 1.1 \text {, } \\
\text { moderate-intensity: }+1.4 \pm 1.7, p=0.04 \text { ) } \\
\text { No change in } \mathrm{VO}_{2} \text { peak in high-intensity interval } \\
\text { training group }\end{array}$ \\
\hline
\end{tabular}

CPET, cardiopulmonary exercise testing; CKD, chronic kidney disease; $\mathrm{VO}_{2}$ peak, peak oxygen uptake; GFR, glomerular filtration rate; eGFR, estimated glomerular filtration rate; $\mathrm{AT}$, anaerobic threshold; $\mathrm{VO}_{2} \mathrm{max}$, maximum oxygen uptake; "isotime", defined as a time when workload was the same in all subjects; PSQI, Pittsburgh sleep quality index; eGFRcysC, estimated glomerular filtration rate from cystatin C measurements; BMI, Body mass index; DEXA, Dual energy $\mathrm{x}$-ray absorptiometry; MDRDcr, modification of diet in renal disease-creatinine; CKD-EPIcr, CKD-epidemiology collaboration using creatinine; CKD-EPIcys, CKD-epidemiology collaboration formula using cystatin C; CKD-EPIcr-cys, CKD-epidemiology collaboration formula using creatinine and cystatin C; MET, metabolic equivalent; FMD, flow-mediated dilation; TC, total cholesterol. ${ }^{\text {a }}$ These 3 reports present the same CPET results of a single trial with different secondary outcomes.

Aoike et al. [59] randomized 40 overweight patients with CKD stage $3-4$ to a home-based- $(n=12)$, a center-based$(n=13)$, and a non-exercise group $(n=15)$, showing that $\mathrm{VO}_{2}$ peak and other CPET parameters were similarly improved after 12 and 24 weeks in both exercise groups. Furthermore, in some of these studies, simultaneous improvements in examined vascular parameters, such as ar- terial stiffness $[49,53,56]$ or peripheral endothelial function [58] were evident.

In contrast to the above findings, there are studies in pre-dialysis CKD patients not suggesting a benefit of exercise training (Table 3) [63-65]. The first study in this field [63], randomizing $30 \mathrm{CKD}$ patients with a median GFR $25 \mathrm{~mL} / \mathrm{min} / 1.73 \mathrm{~m}^{2}$ to a physical training group and 
a usual lifestyle group, showed numerically but nonsignificantly higher $\mathrm{VO}_{2}$ peak in the exercise group after 18 months of follow-up. Leehey et al. [64], randomly assigned 36 CKD patients with obesity and type 2 diabetes to "exercise and diet" versus "diet" intervention, reporting no differences in $\mathrm{VO}_{2}$ peak between the groups at either 12 or 52 week of follow-up. Finally, in the largest trial of the field, Ikizler et al. [65] randomized 111 obese patients with CKD into 4 groups: exercise \& calorie restriction; usual activity \& calorie restriction; exercise \& usual diet; and usual activity \& usual diet. After 4 months of follow-up, no significant difference in $\mathrm{VO}_{2}$ peak in the exercise compared to the non-exercise groups were noted, regardless of the diet intervention.

The effect of exercise training on CPET parameters in patients with CKD has been also examined in recent meta-analyses, which show pooled estimates of improved $\mathrm{VO}_{2}$ peak $/ \mathrm{VO}_{2}$ max with physical rehabilitation programs $[66,67]$. It is not yet clear, why exercise training did not improve cardiorespiratory fitness of CKD patients in all relevant studies. One should first note that careful interpretation is needed before considering a study as positive or negative, since results are reported in different ways in individual studies, i.e., as within-group comparisons (baseline vs. post-intervention), between-group comparisons (of change from baseline or post-intervention values), or as group-by-time interactions. Small study samples, or inadequate duration of training programs may apply to some cases [63], although these were also features of some positive pilot studies [50,62]. Characteristics of the included populations may also affect each study results, as meta-regression analyses suggest that older age, obesity, and diabetes may be factors leading to poor exercise response $[67,68]$.

\section{Potential Clinical Applications of CPET in Patients with CKD}

CPET is a highly useful clinical tool that evaluates organ-specific maladaptive physiological responses which may limit physical performance. It provides breath-bybreath gas exchange measures while progressively increasing exercise intensity in a linear function over time to maximally stress the oxygen delivery and utilization system [24]. CPET may have a wide range of clinical applications that can help to better characterize the cardiopulmonary phenotype of patients with CKD. As discussed above, exercise limitation in patients with CKD can be attributed to a wide variety of coexisting disorders of the cardiac, respiratory, nervous, and muscular systems that can be directly or indirectly linked with reduced renal function $[18,19]$. As CPET is the optimal tool in the differential diagnosis of conditions associated with reduced cardiovascular reserve, it may help towards the identification of previously "hidden" causes of poor exercise capacity in patients with pre-dialysis $\mathrm{CKD}$, such as respiratory functional disturbances and neuromuscular disorders [69]. Moreover, CPET use, through discrimination of the underlying causes of physical impairment and exertional fatigue in CKD patients, who suffer from multiple comorbidities, may facilitate treatment optimization towards symptom relief and functional capacity improvement. Furthermore, as exercise training has shown to improve physical function and walking capacity among subjects with CKD [68], CPET could be used to identify individuals with impaired exercise tolerance that would benefit from intervention. In addition, it can provide valuable information before the initiation of training, i.e., determine the optimal training intensity level and exercise safety, and after program completion, i.e., evaluate the efficacy of the intervention [28].

CPET is also used for several years in preoperative evaluation of different patient groups, including patients before heart surgery or organ transplantation (including heart, lung, and liver) [70]. CPET information can be used to inform the decision-making and consent processes, to direct preoperative interventions, intraoperative anesthetic practice, prehabilitation, and rehabilitation, as well as to estimate the likelihood of perioperative morbidity and mortality. To this end, $\mathrm{VO}_{2}$ peak and $\mathrm{VO}_{2} \mathrm{AT}$ are the CPET variables with the higher prognostic value in subjects before major surgeries, as well as in patients with end-stage CKD waitlisted for kidney transplantation [15, $70,71]$. However, there is very little, if any, use of CPET evaluation in CKD patients in preoperative clinical practice. Further, CPET is currently used for long-term risk stratification in a wide range of populations, such as patients with lung diseases and heart failure. For example, in patients with chronic obstructive pulmonary disease, CPET has been used to predict the risk of all-cause mortality, independently of lung function indices [72], while in patients with heart failure, CPET offers incremental value beyond clinical characteristics and ejection fraction in predicting the risks of hospitalization and mortality [73]. However, to our knowledge, there is no risk stratification tool including CPET parameters for CKD patients. As individuals with CKD share several comorbidities with the aforementioned disease populations $[74,75]$, it would be interesting for future research to examine whether 
CPET parameters are associated with relevant outcomes and, as such, they can be used for risk stratification with regards to perioperative complications or long-term cardiovascular and all-cause mortality in patients with CKD.

Finally, as randomized trials in nephrology with hard endpoints (i.e., death or cardiovascular events) are difficult to perform and scarce, several studies, including elegant randomized research efforts in patients with CKD include intermediate cardiac end points, such as left-ventricular mass index and left-ventricular ejection fraction $[76,77]$. As of this writing, trials in other patient populations (i.e., individuals with heart failure) have used CPET parameters as intermediate cardiovascular endpoints [78, 79]. On this basis, using comprehensive CPET end points could be a valid option also for cardiorenal outcome trials [69]; for this to happen, long-term and optimally designed studies should first evaluate the association of key CPET parameters, such as $\mathrm{VO}_{2}$ peak, with key outcomes such as cardiovascular and all-cause mortality specifically in patients with CKD.

\section{Conclusions}

CKD has a prevalence of $9-12 \%$ in Western societies and is per se associated with increased risk for cardiovascular events and all-cause mortality. Among patients with $\mathrm{CKD}$, cardiovascular disease is the leading cause of death. Existing studies suggest that exercise intolerance is an inherent disturbance of CKD patients resulting in inactivity, deconditioning, diminished functional capacity, feeling of tiredness, social isolation, and impaired quality of life. As of this writing, CPET has been used in pilot observational studies that, in most cases, examine exercise capacity in patients with CKD versus non-CKD controls and, in some cases evaluate simple associations with other vascular parameters, such as endothelial function and arterial stiffness. In addition, CPET has been used in randomized trials examining the effect of exercise training interventions on cardiovascular reserve in patients with $\mathrm{CKD}$, in order to obtain an objective measure of exercise tolerance. However, CPET may have an array of additional applications in patients with $\mathrm{CKD}$, ranging from objective differential diagnosis of exercise intolerance to preoperative and long-term risk stratification and providing comprehensive intermediate endpoints for clinical trials. Overall, future studies using CPET in patients with pre-dialysis CKD in order to examine its diagnostic accuracy for underlying diseases, to delineate the associations of CPET indexes with cardiac and vascular parameters that represent well-known cardiovascular risk factors, as well as to directly assess the prognostic significance of CPET derived indexes for hard outcomes, can be particularly useful in order to establish CPET as a valid diagnostic and prognostic tool for the benefit of our patients.

\section{Statement of Ethics}

This is a literature review manuscript and therefore ethics approval was not applicable.

\section{Conflict of Interest Statement}

All authors disclose that they do not have any financial or other relationships, which might lead to a conflict of interest regarding this paper.

\section{Funding Sources}

This paper was not supported by any source and represents an original effort of the authors.

\section{Author Contributions}

A.B. and P.S.: conception of the manuscript; E.P. and M.T.: literature search; E.P. and A.B.: manuscript drafting; P.S.: critical revision of the manuscript for intellectual content.

\section{References}

1 Levey AS, Eckardt KU, Tsukamoto Y, Levin A, Coresh J, Rossert J, et al. Definition and classification of chronic kidney disease: a position statement from Kidney Disease: Improving Global Outcomes (KDIGO). Kidney Int. 2005 Jun;67(6):2089-100.

2 Jager KJ, Kovesdy C, Langham R, Rosenberg $\mathrm{M}$, Jha $\mathrm{V}$, Zoccali C. A single number for advocacy and communication-worldwide more than 850 million individuals have kidney diseases. Kidney Int. 2019 Nov;96(5):1048-50.
3 GBD Chronic Kidney Disease Collaboration. Global, regional, and national burden of chronic kidney disease, 1990-2017: a systematic analysis for the Global Burden of Disease Study 2017. Lancet. 2020 Feb;395(10225):709-33.

4 Foreman KJ, Marquez N, Dolgert A, Fukutaki K, Fullman N, McGaughey M, et al. Forecasting life expectancy, years of life lost, and all-cause and cause-specific mortality for 250 causes of death: reference and alternative scenarios for 2016-40 for 195 countries and territories. Lancet. 2018 Nov;392(10159):2052-90. 
5 Levin A, Stevens PE, Bilous RW, Coresh J, De Francisco ALM, De Jong PE, et al., Kidney disease: Improving global outcomes (KDIGO) CKD work group. KDIGO 2012 clinical practice guideline for the evaluation and management of chronic kidney disease. Kidney Int Suppl. 2013;3(1):1-150.

6 Go AS, Chertow GM, Fan D, McCulloch CE, Hsu CY. Chronic kidney disease and the risks of death, cardiovascular events, and hospitalization. N Engl J Med. 2004 Sep;351(13):1296305.

7 Georgianos PI, Sarafidis PA, Lasaridis AN. Arterial stiffness: a novel cardiovascular risk factor in kidney disease patients. Curr Vasc Pharmacol. 2015;13(2):229-38.

8 Karpetas A, Sarafidis PA, Georgianos PI, Protogerou A, Vakianis P, Koutroumpas G, et al. Ambulatory recording of wave reflections and arterial stiffness during intra- and interdialytic periods in patients treated with dialysis. Clin J Am Soc Nephrol. 2015 Apr;10(4):630-8.

9 Korogiannou M, Xagas E, Marinaki S, Sarafidis $\mathrm{P}$, Boletis JN. Arterial stiffness in patients with renal transplantation; associations with comorbid conditions, evolution, and prognostic importance for cardiovascular and renal outcomes. Front Cardiovasc Med. 2019;6:67.

10 Mathew RO, Bangalore S, Lavelle MP, Pellikka PA, Sidhu MS, Boden WE, et al. Diagnosis and management of atherosclerotic cardiovascular disease in chronic kidney disease: a review. Kidney Int. 2017 Apr;91(4):797-807.

11 Imboden MT, Harber MP, Whaley MH, Finch WH, Bishop DL, Kaminsky LA. Cardiorespiratory fitness and mortality in healthy men and women. J Am Coll Cardiol. 2018 Nov;72(19): 2283-92.

12 Wilkinson TJ, Watson EL, Vadaszy N, Baker LA, Viana JL, Smith AC. Response of the oxygen uptake efficiency slope to exercise training in patients with chronic kidney disease. Kidney Res Clin Pract. 2020 Sep;39(3):305-17.

13 Zelle DM, Klaassen G, van Adrichem E, Bakker SJ, Corpeleijn E, Navis G. Physical inactivity: a risk factor and target for intervention in renal care. Nat Rev Nephrol. 2017 Mar;13(3):152-68.

14 Kirkman DL, Muth BJ, Stock JM, Townsend RR, Edwards DG. Cardiopulmonary exercise testing reveals subclinical abnormalities in chronic kidney disease. Eur J Prev Cardiol. 2018 Nov;25(16):1717-24.

15 Ting SM, Iqbal H, Kanji H, Hamborg T, Aldridge N, Krishnan N, et al. Functional cardiovascular reserve predicts survival pre-kidney and post-kidney transplantation. J Am Soc Nephrol. 2014 Jan;25(1):187-95.

16 Johansen KL, Kaysen GA, Dalrymple LS, Grimes BA, Glidden DV, Anand S, et al. Association of physical activity with survival among ambulatory patients on dialysis: the Comprehensive Dialysis Study. Clin J Am Soc Nephrol. 2013 Feb;8(2):248-53.

17 Sietsema KE, Amato A, Adler SG, Brass EP. Exercise capacity as a predictor of survival among ambulatory patients with end-stage renal disease. Kidney Int. 2004 Feb;65(2):719-24.
18 Heiwe S, Clyne N, Dahlgren MA. Living with chronic renal failure: patients' experiences of their physical and functional capacity. Physiother Res Int. 2003;8(4):167-77.

19 Heiwe S, Jacobson SH. Exercise training for adults with chronic kidney disease. Cochrane Database Syst Rev. 2011 Oct 5(10):CD003236.

20 Gibbons RJ, Balady GJ, Bricker JT, Chaitman BR, Fletcher GF, Froelicher VF, et al. ACC/ AHA 2002 guideline update for exercise testing: summary article. A report of the American College of Cardiology/American Heart Association Task Force on Practice Guidelines (Committee to Update the 1997 Exercise Testing Guidelines). J Am Coll Cardiol. 2002 Oct; 40(8):1531-40.

21 ERS Task Force; Palange P, Palange P, Ward SA, Carlsen KH, Casaburi R, Gallagher CG, et al. Recommendations on the use of exercise testing in clinical practice. Eur Respir J. 2007 Jan;29(1):185-209.

22 Shafiq A, Brawner CA, Aldred HA, Lewis B, Williams CT, Tita C, et al. Prognostic value of cardiopulmonary exercise testing in heart failure with preserved ejection fraction. The Henry Ford HospITal CardioPulmonary EXercise Testing (FIT-CPX) project. Am Heart J. 2016 Apr;174:167-72.

23 Albouaini K, Egred M, Alahmar A, Wright DJ. Cardiopulmonary exercise testing and its application. Heart. 2007 Nov;93(10):128592.

24 American Thoracic Society, American College of Chest Physicians. ATS/ACCP Statement on cardiopulmonary exercise testing. Am J Respir Crit Care Med. 2003 Jan;167(2):211-77.

25 Wasserman K, Hansen JE, Sietsema KE, Sue DY, Stringer W, Sun X, et al. Principles of exercise testing and interpretation: including pathophysiology and clinical applications. 5th ed. Philadelphia, PA: Lippincott Williams \& Walter (LWW); 2011.

26 Wasserman K, Hansen JE, Sue DY, Stringer W, Whipp BJ. Principles of exercise testing and interpretation: Including Pathophysiology and Clinical Applications. 4th ed PA: Lippincott Williams and Wilkins; 2004.

27 Guazzi M, Adams V, Conraads V, Halle M, Mezzani A, Vanhees L, et al. EACPR/AHA Scientific Statement. Clinical recommendations for cardiopulmonary exercise testing data assessment in specific patient populations. Circulation. 2012 Oct;126(18):2261-74.

28 Boutou AK, Zafeiridis A, Pitsiou G, Dipla K, Kioumis I, Stanopoulos I. Cardiopulmonary exercise testing in chronic obstructive pulmonary disease: an update on its clinical value and applications. Clin Physiol Funct Imaging. 2020 Jul;40(4):197-206.

29 Wasserman K, Whipp BJ. Excercise physiology in health and disease. Am Rev Respir Dis. 1975 Aug;112(2):219-49.

30 Herdy AH, Ritt LE, Stein R, Araújo CG, Milani M, Meneghelo RS, et al. Cardiopulmonary exercise test: background, applicability and interpretation. Arq Bras Cardiol. 2016 Nov; 107(5):467-81.
31 Mezzani A. Cardiopulmonary exercise testing: basics of methodology and measurements. Ann Am Thorac Soc. 2017 Jul; 14(Suppl 1):S3-11.

32 Boutou AK, Stanopoulos I, Pitsiou GG, Kontakiotis T, Kyriazis G, Sichletidis L, et al. Anemia of chronic disease in chronic obstructive pulmonary disease: a case-control study of cardiopulmonary exercise responses. Respiration. 2011;82(3):237-45.

33 Maron BA, Cockrill BA, Waxman AB, Systrom $\mathrm{DM}$. The invasive cardiopulmonary exercise test. Circulation. 2013 Mar;127(10): 1157-64.

34 Hammer SM, Alexander AM, Didier KD, Huckaby LM, Barstow TJ. Limb blood flow and muscle oxygenation responses during handgrip exercise above vs. below critical force. Microvasc Res. 2020 Sep;131:104002.

35 Haykowsky MJ, Tomczak CR, Scott JM, Paterson DI, Kitzman DW. Determinants of exercise intolerance in patients with heart failure and reduced or preserved ejection fraction. J Appl Physiol. 2015 Sep;119(6):739-44.

36 Puente-Maestu L. Physiological rationale of commonly used clinical exercise tests. Pulmonology. 2020 May-Jun;26(3):159-65.

37 Kirkman DL, Bohmke N, Carbone S, Garten RS, Rodriguez-Miguelez P, Franco RL, et al. Exercise intolerance in kidney diseases: physiological contributors and therapeutic strategies. Am J Physiol Renal Physiol. 2021 Feb 1; 320(2):F161-73.

38 Brooks GA. Anaerobic threshold: review of the concept and directions for future research. Med Sci Sports Exerc. 1985 Feb;17(1): 22-34.

39 Vogiatzis I, Zakynthinos G, Andrianopoulos V. Mechanisms of physical activity limitation in chronic lung diseases. Pulm Med. 2012; 2012:634761

40 Pechter U, Ots M, Mesikepp S, Zilmer K, Kullissaar T, Vihalemm T, et al. Beneficial effects of water-based exercise in patients with chronic kidney disease. Int J Rehabil Res. 2003 Jun;26(2):153-6.

41 Boyce ML, Robergs RA, Avasthi PS, Roldan C, Foster A, Montner P, et al. Exercise training by individuals with predialysis renal failure: cardiorespiratory endurance, hypertension, and renal function. Am J Kidney Dis. 1997 Aug;30(2):180-92.

42 Nelson A, Otto J, Whittle J, Stephens RC, Martin DS, Prowle JR, et al. Subclinical cardiopulmonary dysfunction in stage 3 chronic kidney disease. Open Heart. 2016;3(1):e000370.

43 Faria Rde S, Fernandes N, Lovisi JC, Reboredo Mde M, Marta MS, Pinheiro Bdo V, et al. Pulmonary function and exercise tolerance are related to disease severity in pre-dialytic patients with chronic kidney disease: a cross-sectional study. BMC Nephrol. 2013 Sep;14:184.

44 Chinnappa S, White E, Lewis N, Baldo O, Tu YK, Glorieux G, et al. Early and asymptomatic cardiac dysfunction in chronic kidney disease. Nephrol Dial Transplant. 2018 Mar; 33(3):450-8. 
45 Van Craenenbroeck AH, Van Craenenbroeck EM, Van Ackeren K, Hoymans VY, Verpooten GA, Vrints CJ, et al. Impaired vascular function contributes to exercise intolerance in chronic kidney disease. Nephrol Dial Transplant. 2016 Dec;31(12):2064-72.

46 Downey RM, Liao P, Millson EC, Quyyumi AA, Sher S, Park J. Endothelial dysfunction correlates with exaggerated exercise pressor response during whole body maximal exercise in chronic kidney disease. Am J Physiol Renal Physiol. 2017 May;312(5):F917-24.

47 Hama T, Oikawa K, Ushijima A, Morita N, Matsukage T, Ikari Y-j., et al. Effect of cardiac rehabilitation on the renal function in chronic kidney disease: analysis using serum cystatin$\mathrm{C}$ based glomerular filtration rate. Int $\mathrm{C}$ Cardiol Heart Vasc. 2018 Jun;19:27-33.

48 Wilkinson TJ, Xenophontos S, Gould DW, Vogt BP, Viana JL, Smith AC, et al. Test-retest reliability, validation, and "minimal detectable change" scores for frequently reported tests of objective physical function in patients with non-dialysis chronic kidney disease. Physiother Theory Pract. 2019 Jun;35(6):565-76.

49 Mustata S, Groeneveld S, Davidson W, Ford G Kiland K, Manns B. Effects of exercise training on physical impairment, arterial stiffness and health-related quality of life in patients with chronic kidney disease: a pilot study. Int Urol Nephrol. 2011 Dec;43(4):1133-41.

50 Leehey DJ, Moinuddin I, Bast JP, Qureshi S, Jelinek CS, Cooper C, et al. Aerobic exercise in obese diabetic patients with chronic kidney disease: a randomized and controlled pilot study. Cardiovasc Diabetol. 2009 Dec;8:62.

51 Headley S, Germain M, Milch C, Pescatello L, Coughlin MA, Nindl BC, et al. Exercise training improves $\mathrm{HR}$ responses and $\mathrm{V}^{\circ} \mathrm{O} 2$ peak in predialysis kidney patients. Med Sci Sports Exerc. 2012 Dec;44(12):2392-9.

52 Howden EJ, Leano R, Petchey W, Coombes JS, Isbel NM, Marwick TH. Effects of exercise and lifestyle intervention on cardiovascular function in CKD. Clin J Am Soc Nephrol. 2013 Sep; 8(9):1494-501.

53 Headley S, Germain M, Wood R, Joubert J, Milch C, Evans E, et al. Short-term aerobic exercise and vascular function in CKD stage 3: a randomized controlled trial. Am J Kidney Dis. 2014 Aug;64(2):222-9.

54 Headley S, Germain M, Wood R, Joubert J, Milch C, Evans E, et al. Blood pressure response to acute and chronic exercise in chronic kidney disease. Nephrology. 2017 Jan;22(1):72-8.

55 Miele EM, Headley SAE, Germain M, Joubert J, Herrick S, Milch C, et al. High-density lipoprotein particle pattern and overall lipid responses to a short-term moderate-intensity aerobic exercise training intervention in patients with chronic kidney disease. Clin Kidney J. 2017 Aug;10(4):524-31.

56 Greenwood SA, Koufaki P, Mercer TH, MacLaughlin HL, Rush R, Lindup H, et al. Effect of exercise training on estimated GFR, vascular health, and cardiorespiratory fitness in patients with CKD: a pilot randomized con- trolled trial. Am J Kidney Dis. 2015 Mar;65(3): 425-34.

57 Aoike DT, Baria F, Kamimura MA, Ammirati A, de Mello MT, Cuppari L. Impact of homebased aerobic exercise on the physical capacity of overweight patients with chronic kidney disease. Int Urol Nephrol. 2015 Feb;47(2):359-67.

58 Van Craenenbroeck AH, Van Craenenbroeck EM, Van Ackeren K, Vrints CJ, Conraads VM, Verpooten GA, et al. Effect of moderate aerobic exercise training on endothelial function and arterial stiffness in CKD stages 3-4: a randomized controlled trial. Am J Kidney Dis. 2015 Aug;66(2):285-96.

59 Aoike DT, Baria F, Kamimura MA, Ammirati A, Cuppari L. Home-based versus centerbased aerobic exercise on cardiopulmonary performance, physical function, quality of life and quality of sleep of overweight patients with chronic kidney disease. Clin Exp Nephrol. 2018 Feb;22(1):87-98.

60 Kirkman DL, Ramick MG, Muth BJ, Stock JM, Pohlig RT, Townsend RR, et al. Effects of aerobic exercise on vascular function in nondialysis chronic kidney disease: a randomized controlled trial. Am J Physiol Renal Physiol. 2019 May;316(5):F898-905.

61 Beetham KS, Howden EJ, Isbel NM, Coombes JS. Agreement between cystatin-C and creatinine based eGFR estimates after a 12-month exercise intervention in patients with chronic kidney disease. BMC Nephrol. 2018 Dec;19(1):366.

62 Beetham KS, Howden EJ, Fassett RG, Petersen A, Trewin AJ, Isbel NM, et al. High-intensity interval training in chronic kidney disease: a randomized pilot study. Scand J Med Sci Sports. 2019 Aug;29(8):1197-204.

63 Eidemak I, Haaber AB, Feldt-Rasmussen B, Kanstrup IL, Strandgaard S. Exercise training and the progression of chronic renal failure. Nephron. 1997;75(1):36-40.

64 Leehey DJ, Collins E, Kramer HJ, Cooper C, Butler J, McBurney C, et al. Structured exercise in obese diabetic patients with chronic kidney disease: a randomized controlled trial. Am J Nephrol. 2016;44(1):54-62.

65 Ikizler TA, Robinson-Cohen C, Ellis C, Headley SAE, Tuttle K, Wood RJ, et al. Metabolic effects of diet and exercise in patients with moderate to severe CKD: a randomized clinical trial. J Am Soc Nephrol. 2018 Jan;29(1): 250-9.

66 Vanden Wyngaert K, Van Craenenbroeck AH, Van Biesen W, Dhondt A, Tanghe A, Van Ginckel A, et al. The effects of aerobic exercise on eGFR, blood pressure and VO2peak in patients with chronic kidney disease stages 3-4: a systematic review and meta-analysis. PLoS One. 2018;13(9):e0203662.

67 Yamamoto R, Ito T, Nagasawa Y, Matsui K, Egawa $M$, Nanami $M$, et al. Efficacy of aerobic exercise on the cardiometabolic and renal outcomes in patients with chronic kidney disease: a systematic review of randomized controlled trials. J Nephrol. 2021 Feb;34(1):155-64.

68 Nakamura K, Sasaki T, Yamamoto S, Hayashi H, Ako S, Tanaka Y. Effects of exercise on kid- ney and physical function in patients with nondialysis chronic kidney disease: a systematic review and meta-analysis. Sci Rep. 2020 Oct; 10(1):18195.

69 Lim K, McGregor G, Coggan AR, Lewis GD, Moe SM. Cardiovascular functional changes in chronic kidney disease: integrative physiology, pathophysiology and applications of cardiopulmonary exercise testing. Front Physiol. 2020 Sep 15;11:572355.

70 Levett DZH, Jack S, Swart M, Carlisle J, Wilson J, Snowden C, et al. Perioperative cardiopulmonary exercise testing (CPET): consensus clinical guidelines on indications, organization, conduct, and physiological interpretation. Br J Anaesth. 2018 Mar; 120(3):484-500.

71 Older PO, Levett DZH. Cardiopulmonary exercise testing and surgery. Ann Am Thorac Soc. 2017 Jul;14(Suppl 1):S74-83.

72 Oga T, Nishimura K, Tsukino M, Sato S, Hajiro $\mathrm{T}$. Analysis of the factors related to mortality in chronic obstructive pulmonary disease: role of exercise capacity and health status. Am J Respir Crit Care Med. 2003 Feb;167(4):544-9.

73 Nadruz W, West E, Sengeløv M, Santos M, Groarke JD, Forman DE, et al. Prognostic value of cardiopulmonary exercise testing in heart failure with reduced, midrange, and preserved ejection fraction. J Am Heart Assoc. 2017 Oct 31;6(11):e006000.

74 Ronco C, McCullough P, Anker SD, Anand I, Aspromonte N, Bagshaw SM, et al. Cardio-renal syndromes: report from the consensus conference of the acute dialysis quality initiative. Eur Heart J. 2010 Mar;31(6):703-11.

75 Brassington K, Selemidis S, Bozinovski S, Vlahos R. New frontiers in the treatment of comorbid cardiovascular disease in chronic obstructive pulmonary disease. Clin Sci. 2019 Apr;133(7):885-904.

76 Sarafidis P, Faitatzidou D, Papagianni A. Benefits and risks of frequent or longer haemodialysis: weighing the evidence. Nephrol Dial Transplant. 2020 Feb 19:gfaa023.

77 Loutradis C, Sarafidis PA, Papadopoulos CE, Papagianni A, Zoccali C. The Ebb and flow of echocardiographic cardiac function parameters in relationship to hemodialysis treatment in patients with ESRD. J Am Soc Nephrol. 2018 May;29(5):1372-81.

78 Edelmann F, Wachter R, Schmidt AG, Kraigher-Krainer E, Colantonio C, Kamke W, et al. Effect of spironolactone on diastolic function and exercise capacity in patients with heart failure with preserved ejection fraction: the aldo-DHF randomized controlled trial. JAMA. 2013 Feb;309(8):781.

79 Udelson JE, Lewis GD, Shah SJ, Zile MR, Redfield MM, Burnett J, et al. Effect of praliciguat on peak rate of oxygen consumption in patients with heart failure with preserved ejection fraction: the CAPACITY HFpEF randomized clinical trial. JAMA. 2020 Oct;324(15):152231.

80 Wasserman K. Diagnosing cardiovascular and lung pathophysiology from exercise gas exchange. Chest. 1997;112(4):1091-1101. 